Удк $340.15(477.5): 334.735$

DOI https://doi.org/10.32837/yuv.v0i4.2209

\author{
Г. Волошкевич, \\ кандидат юридичних наук, доцент, \\ доцент кафедри державно-правових дисциплін \\ Черкаського національного університету імені Богдана Хмельницького
}

\title{
СТАТУТИ ПЕРШИХ УКРАЇНСЬКИХ СПОЖИВЧИХ ТОВАРИСТВ ЯК НОРМАТИВНО-ПРАВОВА ОСНОВА ÏХ ФУНКЦІОНУВАННЯ (СЕРЕДИНА ХІХ СТ.)
}

Постановка проблеми. Однією з малодосліджених проблем вітчизняної історико-правової науки є становлення і розвиток кооперативного законодавства в середині XIX - на початку XX століття. Не дивлячись на доволі значний масив історичного матеріалу, дослідники практично не приділяють уваги зародженню i розвитку інститутів дореволюційного кооперативного права. Основна частина наявних публікацій присвячена характеристиці положень загального кооперативного закону від 20.03.1917 р. Відповідно створюється враження, що до 1917 року будь-яке правове регулювання споживчо-кооперативного руху було відсутнє. Насправді ситуація складалася зовсім інакше. Протягом середини XIX - початку XX століття тривав інтенсивний розвиток кооперативних організацій, що зумовило виникнення оригінальної нормативно-правової бази кооперації, яка відрізнялася не лише від європейських аналогів, але мала відмінності в межах окремих регіонів Російської імперії. Насамперед йдеться про перші етапи становлення і розвитку кооперативних організацій, вимушених діяти в умовах відсутності чіткого правового регулювання, що, в свою чергу, обумовило виникнення різноманітних за змістом статутів перших кооперативів.

Мета дослідження - аналіз змісту установчих документів перших споживчих товариств і дії закріплених у них норм на землях Наддніпрянської України. Це не лише дозволить прослідкувати процес становлення основних інститутів кооперативного права, але й дасть можливість визначити регіональні особливості української кооперації, яскраво виражені саме в цей період. Додатковим завданням $€$ здійснення порівняльного аналізу установчих документів вітчизняних та європейських споживчих товариств.

Вихідною точкою відліку зародження споживчої кооперації на українських землях слід вважати створення в 1866 році Харківського споживчого товариства. Ініціатива його заснування належить групі представників харківської інтелігенції, серед яких насамперед слід виділити М. Балліна, О. Брильянтова, Є. Гордієнко, О. Горніч-Гарницького та інших [1, арк. 140-141].

Досить швидко виявилися й позитивні економічні наслідки від діяльності Харківського споживчого товариства. Продаючи у своїх крамницях якісні та порівняно дешеві товари, харківські кооператори не лише почали заощаджувати власні кошти, але й змусили приватних крамарів піти на серйозне зменшення цін у власних торговельних закладах. Про серйозність конкуренції, яка виникла між кооператорами та приватними торгівцями, можуть свідчити такі слова одного з харківських купців: «споживчі крамниці хочуть зни- 


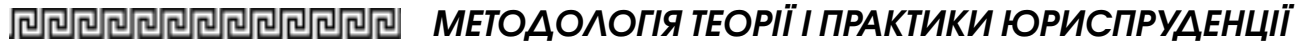

щити купецьку верству. Ми будемо просити уряд, щоб вас обмежили» [2, с. $14,92-93]$.

Завдяки широкому висвітленню діяльності Харківського споживчого товариства у місцевій пресі, успіхи харків'ян стали широко відомі в усіх куточках Наддніпрянської України, що призвело до пожвавлення кооперативного руху у цьому регіоні. У 1867 році споживче товариство було відкрите мешканцями Одеси, наступного року - жителями Катеринослава, Києва, Лебедина, Миколаєва, Полтави та Херсону. У 1867 році споживчі кооперативи з'явилися в Борзні, Балті, Ізюмі, Єлисаветграді, Чернігові [3, с. 97]. Активність українців на цій новій для них кооперативній ниві була вражаючою - $з 70$ споживчих товариств, що виникли протягом 60-70-х років XIX століття в Російській імперії, на території українських губерній знаходилося, за різними підрахунками, від 17 до 21 об'єднань цього типу, тобто майже $1 / 3$ від загальної ї кількості [5, с. 46-48].

Отже, наведені нами цифри свідчать, що українська споживча кооперація посідала провідне місце в загальноросійському кооперативному русі, відтак могла суттєво впливати на практику й теорію кооперативного будівництва в країні. Означений висновок спонукає нас до детального аналізу статутів перших товариств із метою отримання відомостей щодо основних принципів і механізму функціонування цих кооперативів.

Перед тим, як перейти до безпосереднього розгляду статутів перших українських товариств, слід звернути увагу на одну досить важливу деталь. У 60-90-х роках XIX століття не існувало єдиних визначених державою вимог щодо форми і змісту статуту кооперативної установи, тому їх укладачі мусили орієнтуватися або на європейські зразки установчих документів, або брати за основу товариські договори існуючих у Росій- ській імперії торгово-промислових товариств чи статути вже чинних кооперативних організацій. У будьякому випадку подібна практика призводила до того, що означені статути, за влучним висловом M. Зібера, нагадували «строкату мозаїку», де «відбувається змішування різноманітних норм, покладених в основу діяльності англійських та німецьких товариств, i до цього додається часом щось зовсім оригінальне» [3, с. 98]. Це дуже ускладнює роботу дослідника, оскільки він повинен або чітко фіксувати всі наявні відмінності та особливості кожного установчого документа, або ж, навпаки, зосередитися на виокремленні найбільш типових, загальних положень, які характеризуватимуть стан кооперативного будівництва в цей період. На нашу думку, другий шлях $€$ більш продуктивним і відповідає дослідницьким завданням, визначеним на початку цього розділу. Тому саме його ми будемо дотримуватися під час нашої подальшої роботи 3 текстами статутів.

Метою діяльності споживчих товариств, визначених у більшості статутних документів, було «покращення матеріального становища своїх членів шляхом доставки їм товарів споживання гарної якості та за дешевими цінами» [5]. Порівняно зі своїми європейськими колегами, які вбачали за необхідне сприяти розвитку не лише матеріальних, але й духовних потреб, вітчизняні кооператори ставили перед собою менш масштабні завдання. Водночас не варто вважати примітивними погляди чи недооцінювати значення світового досвіду. Формулювання мети відображало реалістичний погляд на потреби українського суспільства та адміністративно-правові умови функціонування кооперативних організацій у середині XIX століття. Подальша історія кооперативних організацій засвідчить, що їм доведеться зіткнутися 3 підозрою щодо поширення в суспільстві «соціалістичних ідей», зв'язків із 
революційними організаціями, уявленням про кооперацію не як про об'єднання економічного, а про спільноту політичного характеру тощо [6, с. 122-123]. За таких умов спроба одразу займатися просвітницькою діяльністю могла мати згубні наслідки для новостворених кооперативних організацій.

Членство в товариствах було індивідуалізованим: до кооперативу зараховувалися фізичні особи, які досягли повноліття і володіли належним обсягом дієздатності. Право колективного членства (юридичної особи) у статутах не визначалося. Аналіз змісту установчих документів перших споживчих товариств Наддніпрянської України засвідчує відсутність у них статевих, національних чи станових цензів у разі вступу до товариств. Водночас відсутність формально-юридичних обмежень насправді не робила ці товариства загальностановими установами, вони носили яскраво виражений аристократичний характер [7, с. 43].

Намагаючись залучити одразу якомога більше коштів, низка товариств допустила серйозну помилку встановила значний пайовий внесок (від 10 до 50 карбованців) [8, с. 88, 100; 9, арк. 34, 36]. Такі значні суми не могли бути сплачені значною частиною зацікавлених у споживчих товариствах осіб, тому піонерам кооперативних організацій довелося шукати акціонерів, здатних погодитися внести необхідну для функціонування суму. Наслідком цього стало порушення одразу двох ключових принципів кооперативної організаціі: рівності та взаємодопомоги.

Відповідно до першого принципу всі члени кооперативної організації повинні були виступати рівними у правах та обов'язках. Натомість для залучення заможних акціонерів їм надавалися додаткові права і привілеї. Так звані «фундатори», або «засновники» товариства, які при вступі повинні були внести пай та сплатити вступний внесок, вважалися повноправними членами товариства й користувалися всіма правами, передбаченими статутом: правом обирати та бути обраним в органи управління товариством, отримувати товари у кредит і дивіденди на внесені ними кошти тощо. Другу групу становили так звані «споживачі», які не вносили жодних обов'язкових платежів, однак їх права порівняно з першою групою були значно вужчими - за «споживачами» закріплювалося лише право робити закупки у крамницях товариства та отримувати частину прибутків від його діяльності [10].

Другий принцип передбачав, що основною метою товариства стане взаємодопомога та покращення матеріальних умов життя всіх членів товариства. Для цього передбачалося шукати кращі товари, продавати їх із невеликою націнкою, повертати частину сплачених за товар коштів. Натомість заможні пайщики насамперед були зацікавлені у швидкому отриманні прибутку та виплаті великих дивідендів на свої внески. Вони розглядали споживчий кооператив як своєрідну форму акціонерного товариства, що відбилося у змісті перших статутів, у котрих було закріплено право особи володіти необмеженою кількістю паїв та гарантування виплат на них дивідендів [11, с. 354].

Відступ від цих принципів мав для низки кооперативних організацій Наддніпрянської України згубні наслідки. Будучи залежними від кількох пайщиків, які разом контролювали левову частку коштів товариства, кооперативні організації перетворювалися на звичайні торговельні заклади або занепадали в разі виходу зі складу товариства (як це, наприклад, сталося в Чернігівському, Севастопольському та Одеському кооперативах) [8, с. 158-159, 205, 249].

Важливе місце у статутах було відведено механізму управління споживчим товариством i контролю за роботою створених органів. 


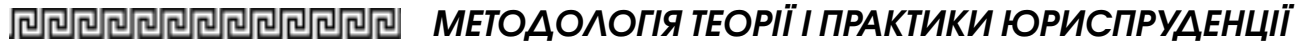

Проведений аналіз статутів свідчить, що переважна більшість кооперативних організацій базувалися на класичній трьохланковій моделі, яка в той період була поширена в європейських кооперативних організаціях: загальні збори, правління, ревізійна комісія.

Вищим органом управління справами товариства були загальні збори його членів, до відання яких належало вирішення більшості важливих питань внутрішнього життя товариства: фінансових, господарських, організаційних, кадрових. Слід відзначити такі особливості організації та роботи цього органу управління в перших товариствах:

- обмеження участі в управлінні товариством, що зокрема проявлялося в забороні брати участь у роботі загальних зборів, осіб, які не внесли повного паю (членів-споживачів). Зокрема, у $§ 9$ статуту Катеринославського споживчого товариства вказано: «Особа, яка не внесла повного паю, не вважається членом товариства і не користується членськими правами» [12, арк. 2].

- суттєве зменшення норми кворуму під час проведення загальних зборів. Зокрема, загальні збори більшості товариств вважалися правомочними за присутністю всього лише 1/5-1/6 загальної кількості пайовиків. Водночас навіть така низька межа часто порушувалася через пасивність пайовиків, що призводило до численних випадків зриву зібрань. Принагідно відзначимо, що способом вирішення цієї проблеми більшість кооперативних організацій вважала не проведення роз'яснювальної роботи серед пайщиків, а механічне зниження мінімальної норми присутності, необхідної для кворуму. Так, члени Київського споживчого товариства постановили вважати загальні збори дійсними, якщо на них з'явилося не $1 / 5$, як раніше, а лише 1/12 від загальної кількості пайовиків. У разі, якщо й ці збори зривалися внаслідок низької явки, наступні вважалися дійсними незалежно від кількості присутніх на них [13, арк. 72-73].

Правління було постійно діючим колегіальним органом, що обирався загальними зборами на термін, визначений у статуті організації. Формально правління залежало від загальних зборів і відповідало перед ними за свою діяльність. На практиці в багатьох товариствах, де існували так звані багатопайщики, правління 3 осіб, які контролювали левову частку уставного капіталу, нав'язувало свою волю іншим кооператорам.

Залежно від наявних знань і вподобань засновників кооперативу у статутах закріплювалась одна з двох поширених у той час моделей розподілу повноважень між членами правління та найманими працівниками. Перша модель, німецька, передбачала безпосередню участь членів правління в оперативній роботі кооперативу, отримуючи за це відповідну платню. Згідно з другою моделлю, англійською, керівництвом поточними справами займався найманий управляючий, а правління лише контролювало його діяльність і виконувало свої функції на громадських засадах [14, с. 92-93]. Водночас аналіз статутів свідчить про розробку українськими кооператорами власних моделей управління, пристосованих до місцевих потреб. Зокрема в Ізюмському товаристві (Харківська губернія) вирішення організаційних питань цілком було покладено на членів правління, які отримували фіксовану платню (німецька модель). Водночас було створено спеціальну посаду управляючого кооперативним товариством, який займався вирішенням суто торговельних питань $[15$, арк. 38].

Важливе місце в системі органів кооперативного самоврядування належало ревізійній комісії. Вона обиралася загальними зборами з числа всіх членів товариства, крім членів правління та осіб, які обіймали в кооперативі оплачувану посаду. Склад комісії 
був невеликий, усього 3-4 особи, що працювали переважно на громадських засадах. На ревізійну комісію покладалося виконання функцій контролю за господарською діяльністю та фінансовим станом товариства. Своє остаточне рішення комісія повинна була оформлювати у вигляді спеціальних звітів, які підлягали затвердженню загальними зборами.

Щодо регулювання господарської діяльності кооперативу, то статути перших споживчих товариств головну увагу приділяли питанням порядку організації торгівлі та порядку розподілу отриманого прибутку. Аналіз відповідних норм показує, що, не дивлячись на наявний досвід європейських кооперативних організацій, перші українські споживчі товариства пройшли аналогічний шлях помилкових рішень і згубних практик, як і більшість їніх попередників. Зокрема, більшість досвідчених кооперативних організацій відмовилися від соціального кредитування своїх членів і продавали товари за середніми ринковими цінами та виключно готівкою. Це рішення було обумовлено розумінням того факту, що в разі незначного стартового капіталу товариство може розвиватися виключно за рахунок швидкого обігу коштів і зміцнення фінансової бази товариства. Натомість у статутах і практиці діяльності перших кооперативних об'єднань Наддніпрянської України ми постійно стикаємося 3 фактами товарного кредитування членів і встановлення цін, набагато нижчих за ринкові [16, арк. 56, 89].

Намагання свідомих членів припинити цю згубну практику призводило до появи гострих конфліктів у самій кооперативної організації із тими пайовиками, які на перше місце ставили задоволення особистих потреб, а не інтереси власного товариства, що спричинило загибель перших кооперативів.

Проблеми виникали також під час розпорядження заробленими коштами. Теорія і практика кооператив- ного руху вимагала, щоб отримані кошти використовувалися для поповнення товарного фонду, виплати заробітної плати, нагородження членів-пайовиків. Ця винагорода повинна була складатися 3 двох частин: перша - у формі повернення членам частини коштів, переплачених ними під час купівлі товарів у товаристві за середніми ринковими цінами; друга - у формі виплати відсотку на суму пайових внесків та інших грошових вкладів пайовика. Перевага, звісно, повинна належати першій премії на забір, оскільки це не лише матеріально стимулює членів кооперативної організації до розширення своїх закупок у крамницях товариства, але й відповідає головній меті діяльності споживчого товариства заощадженню коштів пайовиків.

Натомість у багатьох статутах ми стикаємося із зовсім іншою практикою розпорядження заробленими товариством коштами: переважна частина чистого прибутку розподілялася між їніми членами у вигляді дивідендів, тоді як частка суми, призначена для компенсації забраного у крамниці товару, була дуже низькою. Зокрема, у Миколаївському та Одеському товариствах співвідношення між премією на забір та премією на капітал (дивідендом) становила 60\% і 40\% відповідно. Характерним є те, що в низці кооперативних організацій статути позбавляли права на отримання премії на забір не лише сторонніх покупців, але й рядових членів товариства, натомість використовуючи ці кошти для виплати дивідендів [12, арк. 5; 15, apk. 33, 35].

Вищезазначене дозволяє зробити висновок, що принципи та механізми господарської діяльності перших споживчих товариств, які знайшли своє відображення у їхніх статутах, за своєю суттю наближалися не стільки до кооперативних товариств, скільки до акціонерних компаній. Цей факт пояснюється, по-перше, приходом до кооперації значної 


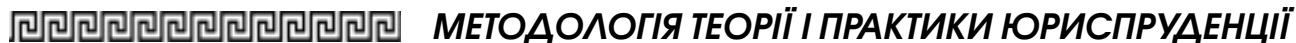

кількості осіб, які розглядали споживчі товариства як новий особливий вид господарської організації i головною метою вбачали отримання значних прибутків із вкладених коштів; по-друге, слід визнати, що за відсутності доступу до зразків статутів діючих європейських споживчих товариств та необхідної повноцінної інформації про специфіку роботи кооперативних організацій розробники статутів перших українських споживчих товариств могли брати за основу наявні статути акціонерних компаній, що загалом обумовило привнесення до установчих документів нехарактерних для споживчої кооперації економічних та юридичних інститутів.

Завершуючи аналіз статутів перших вітчизняних споживчих товариств, можна констатувати, що під час розробки ї змісту вітчизняні піонери кооперативного руху взяли за основу установчі документи й досвід організації споживчих товариств європейських країн. Про це, зокрема, свідчить спільність принципів організації управління товариством та здійснення ним господарської діяльності. Водночас наведені нами факти переконливо свідчать про недотримання споживчими товариствами Наддніпрянської України в середині 60-70-х років XIX століття окремих базових вимог, що висувалися до кооперативної організації теорією та практикою світового кооперативного руху в XIX столітті.

У статті розглянуто нормативно-правову базу функціонування перших споживчих товариств Наддніпрянської України у період іх зародження в другій половині ХІХ століття. Проаналізовано особливості адміністративно-правових умов зародження споживчої коопераціі та розглянуто зміст статутів перших споживчих товариств. Встановлено, щзо від- cутність єдиного законодавчого акту у сфері кооперації обумовило виникнення досить різноманітних за обсягом та змістом установчих документів.

Охарактеризовано основні ключові положення установчих документів кооперативних організацій Наддніпрянської України ü особливості правого статусу перших кооператорів, визначено притаманний першим кооперативним організаціям поділ членів споживчого товариства на повноправних, які володіли всіма закріпленими у статутах правами, та неповноправних, обсяг прав яких мав звужений характер порівняно з першою групою. Відтворено механізм управління споживчими товариствами, визначено основні органи управління (загальні збори, правління, ревізійна комісія), проаналізовано їхній склад i порядок формування. Шляхом порівняльного аналізу встановлено спільні та відмінні риси в установчих документах перших вітчизняних споживчих кооперативів та їх європейських аналогів. Установлено, що, незважаючи на cymmeву схожість, cmamymu перших товариств допускали відступи від загальноприйнятої теорії $i$ практики кооперативного руху, зокрема допускалося обменення прав членів кооперативних організацій. У статутах не було положень, які передбачали повернення частини коштів за придбаний товар, натомість основна увага приділялася виплаті дивідендів. Зроблено висновок, що статути перших споживчих товариств містили окремі норми та інститути, притаманні акціонерним компаніям.

Ключові слова: статут, установчі документи, кооперативне законодавство, кооператив, споживче товариство, правовий статус кооперативних товариств. 
Voloshkevych H. Statutes of the first Ukrainian consumer societies as a normative-legal basis of their functioning (middle of the XIX century)

The article investigates organizationallegal background of consumer's societies and their unions in Nadnepryanska part of Ukraine in the second half of 19th. The peculiarities of administrative and legal conditions for the origin of consumer cooperatives are analyzed and the content of the statutes of the first consumer societies is considered. It has been established that the lack of a single legislative act in the field of cooperation caused the emergence of sufficiently diverse volume and content of constituent documents.

The main key provisions of the constituent documents of cooperative organizations in Nadnepryanska part of Ukraine are characterized, the peculiarities of the right status of the first co-operators are characterized, are characterized by the first cooperative organizations of the division of members of the consumer society on full, owned by all enshrined in the statutes of rights, and disadvantaged, the volume of rights of which had a narrowed character in comparison with the first group. The mechanism of management of consumer societies reproduced, the main management bodies (General Meeting, Board, Audit Commission) are determined), their composition and procedure for formation are analyzed. By comparative analysis, joint and excellent features are established in the constituent documents of the first domestic consumer cooperatives and their european analogues. It has been established that despite the substantial similarity, the statutes of the first societies allowed departments from the generally accepted theory and practice of cooperative movement, in particular, the restriction of the rights of members of cooperative organizations was allowed, there were no provisions that envisaged the return of funds for acquired goods, instead, the main focus was to pay attention to payments dividends. It is concluded that the statutes of the first consumer societies absorbed separate norms and institutions inherent in joint stock companies.

Key words: cooperative movement, cooperative organizations, consumer's society statute, constituent documents, legal status of cooperative societies.

\section{Лiтература}

1. Баллин Н.П. Пятьдесят лет моей жизни. Развитие моих соииальных стремлений. Інститут рукопису Національної бібліотеки імені В.I. Вернадського (Далі - ІР НБУВ). Ф. 326. № 3. 230 с.

2. Марков В.И. Пионеры южно-русской потребительской кооперации: Н.П. Балин и его сотрудники. Харьков : Издательство «ПОЮР

3. Зибер Н. Потребительные общества. Киев: В типографии Е.Я. Федорова 1869. $105 \mathrm{c}$

4. Баллин Н. Первая памятная книжка русских потребительных обществ. Спб. : Общественная польза, 1870. 49 с.

5. ІР НБУВ. Ф. 290. № 4623. арк. 14, 31, 34; ІР НБУВ. Ф. 290. № 3484. арк. 1.

6. Волошкевич Г. А. Адміністративно-правові умови розвитку союзів споживчих товариств Наддніпрянської Украіни наприкінці XIX - на початку XX cm. Вісник Харківського національного університету внутрішніх справ. 2006. № 33. С. 117-123.

7. Волошкевич Г. Зародження споживчої кооперації в Наддніпрянській Україні та правове регулювання ї діяльності в 60-90-х рр. XIX cm. Вісник Запорізького державного університету. Юридичні науки. 2004. № 1. С. 41-47.

8. Сборник материалов об артелях в России. Потребительные обиества. Спб. : Издание Санкт-Петербургского отделения Комитета о сельских судосберегательных и промышленных товариществах. Tuп. Майкова, 1875. Bып. 3. 396 с. 


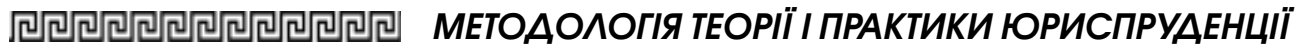

9. ІР НБУВ. Ф. 290. № 4623. 48 арк. ществах. Тип. Майкова, 1874. Bып. 2. 10. ІР НБУВ. Ф. 290. № 134. арк. 12; 372 C.

169, арк. 34-36; ІР НБУВ. Ф. 290. № 4623. арк. 4.

11. Сборник материалов об артелях в России. Потребительные общества. Спб. : Издание Санкт-Петербургского отделения Комитета о сельских ссудо-сберегательных и промышленных товари-

12. ІР НБУВ. Ф. 290. № 3484. 6 арк.

13. ІР НБУВ. Ф. 290. № 134. 260 арк.

14. Файн Л.Е. Отечественная кооперация: Исторический опыт. Нваново. 1994. 273 C.

15. ІР НБУВ. Ф. 290. № 4623. 48 арк.

16. ІР НБУВ. Ф. 290. № 4138. 133 арк. 